\title{
The Impact of Early Marriage and Low Level of Education on Agricultural Development in Sub-Saharan Africa
}

\author{
Jude Uwaoma Nwachukwu \\ Columbia University, New York, USA
}

\begin{abstract}
This study tracks the impact of early marriage and low level of education on agricultural development in SSA. Pitching itself within two Nigerian agrarian communities: The study worked with 50 randomly selected farming households from each site. Data was collected through in-depth one-on-one and follow-up interviews, questionnaires, and direct observation. Extensive multivariate and descriptive statistical analysis, tables and charts were used for data interpretation. Combining data-sets from the two sites and between families the study found that early marriage inhibits farmers' chances for education which in turn compounds their situation; those who married early with little or no education tend to have large families and suffer higher poverty incidence; children from such families often repeat the same cycles and so trapped in poverty; farmers who did not fall into this twin situation fared far much better on all counts in addition to exhibiting higher motivation to better their social capital and family socioeconomics; those in the first group are discouraged especially by the responsibility of fending for their many children. The study concludes that these two factors stand in the way to realizing the MDGs among SSA rural farmers; accordingly, some policy recommendations are put forward to address the situation.
\end{abstract}

Keywords: early marriage, education, poverty, MDGs

\section{Introduction}

The overarching importance of agriculture in the economy of Nigeria as with other nations of Sub-Saharan Africa (SSA) cannot be overemphasized (Krishna \& Zackmann, 2008, p. 1; Morgan \& Solarz, 1994; Omorogiuwa et al., 2014; USAID, $1997^{1}$ ). It is the sector that, in addition to being the source of nutrition, provides employment forgreater majority of the population (FARA, 2006 ${ }^{2}$ ), on-farm and off-farm wages for rural and non-rural labor (Annor-Frempong, 2012, p. 1019), raw materials for agro-based industries, and contributes significantly to the Gross Domestic Product (GDP) of SSA (Ake, 1996). Based on these and other facts, agriculture portends more than other sectors to the reduction of poverty and the promotion of sustainable growth of the region's economy (Adewale et al., 2008, p. 77).

Ironically, agriculture is also the sector that has suffered and still suffers many setbacks arising above all from “[...] governmental neglect [....]" (Adewale et al., 2008, p. 77; Ake, 1996). In addition to public sector neglect, many other studies identify different factors including but not limited to elite corruption (Ake, 1996;

Jude Uwaoma Nwachukwu, Ph.D., Applied Anthropology, Department of International and Transcultural Studies, Teachers College, Columbia University.

1 USAID, 1997, Foreign Travel Data Sheet.

2 FARA, 2006, Coordinator for Mechanism for Improving Tertiary Agricultural Education in Africa: Terms of Reference for the Position of Consultant-Coordinator. 
Oyeshile, 2015); incessant intra-inter-ethnic conflict (Morgan \& Solarz, 1994; Achodo, 2000; Arias et al., 2013; Kimenyi et al., 2014); lack of good infrastructure (UN, 2008, p. 1; Jouanjean, 2013, p. 3); inadequate allocation of investment fund to the sector (Ake, 1996; Adewale et al., 2008, p. 77); social organization related institutions such as land tenure systems that often stand in the way of growth in agricultural production (Forde \& Scott, 1946, pp. 64-5; FAO, 2002); weather conditions like drought (AfDB, 2012; Grilj, 2013; McDonald, 2000; European Commission, 2016), among a host other factors.

However, paying some close attention to the varied interest areas of the many studies tracking the performance of the agriculture sector of SSA reveals that not much attention has been accorded the fact of how farmers' personal and social capital affects them and the agriculture sector of the region. This scantiness of attention to this aspect partly accounts for the absence of comprehensive knowledge of the region's agriculture sector.

As such this study is dedicated to examining how the age at which a farmer marries and his or her level of education impact his or her production performance. More specifically, the study examines how these two variables underpinning a farmers' personal and social capital impact him and his household. This is the main preoccupation of this study and also constitutes its intended distinguishing contribution to the on-going overall discourse on agriculture in the whole gamut of the region's economic and social development.

In pursuance of this objective, this introductory part will be followed with laying out the background of the study; this in turn will be followed with laying out the methodology employed in the research including study questions; data collection techniques and data analysis instruments; the theoretical framework on which the study is predicated will follow these. After these the study findings will be laid out and will open us to the discussion section. Finally, the study concludes with policy recommendations targeting improving farmers' personal and social capital for overall improvement of agricultural development in SSA.

\section{Study Background}

The background to this study lies in the fact that all aspects of what makes for sustainable agricultural development in SSA as everywhere else should, of necessity, be examined in order to fully grasp and effectively overcome problems associated with food shortage, hunger, poverty, unemployment among others associated with backwardness in rural and community development. While all other aspects in the search for how to make the agriculture sector of SSA sustainable almost always focus on macro areas as were outlined in the introduction, the micro, more specific aspects come down to the immediate conditions of individual farming households.

The need for this comprehensive search for improved agricultural performance in SSA is based on the fact, as has been illustrated, that agriculture is the key source of sustenance for populations of SSA. Adewale et al. (2008), writing about Nigeria, for example, state: “Agriculture is the key to sustainable livelihood in Nigeria engaging about $60 \%$ to $70 \%$ of the population. Agriculture, therefore has great potential for micro- and macro-economic growth and development in Nigeria” (p. 77). One can assuredly join Zachmann (2014, p. 1) in saying the same thing about other nations of SSA.

Conflicts, though avoidable and preventable, always erupt being part of the relationship between communities (and nations). Natural disasters such as drought and fire outbreaks - both of which adversely affect farmers when they occur-may not fall within the grips of human prevention even with a nation's sophisticated weather-watch machinery. Market conditions affecting prices of agricultural produce are not 
always preventable with unforeseeable extraneous factors. And many more.

When it comes to what makes for farmers' personal and social capital management, however, we are handling matters that can be directly controlled when appropriate private and public sector choices are put in place. Incidentally, this aspect has not attracted as much needed and urgent study and policy action in the whole effort to reduce poverty and realize sustainable agriculture in SSA.

The thrust of our argument here is that, everything about agricultural development plans should be about and around the farmer as the agent of agricultural production; regrettably, this is "[...] a condition that has not been true in Africa [....]" (Ake, 1996, p. 126). And this is why, we mount the argument, that sustainability in the economics of agriculture in SSA has remained a mirage all national, regional and international interventions notwithstanding. For, farming and its correlates are not run by and on the wheels of programs; instead human beings - farmers - are the actual agents that move forward and sustain agricultural production. That being the case, farmers as agents of agricultural development must as well be seen and treated as the means and end of its prospects. This is the sole reason this study is focused on what makes for improving the state of farmers' personal and social capital.

One of the ways to bring this whole pursuit to a comprehensive and effective level is by turning attention to, and searching for, how the phenomena of early marriage and low level of education or total lack thereof separately and collectively impact farmers in SSA. Understanding this while groping for how best to respond to it is the sole reason this study was undertaken.

The research occurred alongside other bigger studies carried out simultaneously by one and the same researcher who, by applying the framework of political economy strives to understand why SSA nations have taken too long to improve the abundant human resources that conduce to making agriculture a great driver of the region's wellbeing.

\section{Study Methodology}

Standing on the foregoing theoretical assumptions the study tracks answers to the questions: In what ways do early marriage and low level of education or total lack thereof impact SSA farmers? In what ways, if any, do these two variables intersect with each other and with farmers' performance in agriculture? What could, and must, be done at both the private and public sector levels to address the issues associated with early marriage and low level of education in order to enhance farmers' productivity? What national, regional and international program interventions have been made to address issues associated with this dual situation?

In attempting these research questions, the study employed a set of research toolkit including in-depth individual interviews, questionnaires, and participant observation in working with a random sample of 50 farmers from each of two sites in Benue and Abia States in Central and Southeastern Nigeria respectively as shown in Figure 1.

Multivariate and descriptive statistical instruments including tables, charts, and percentages were applied in field data analysis. Keeping agricultural production constant, the study explored how the two variables impact farming households in SSA. Some anthropological metanarrative style will play into reporting study results. 


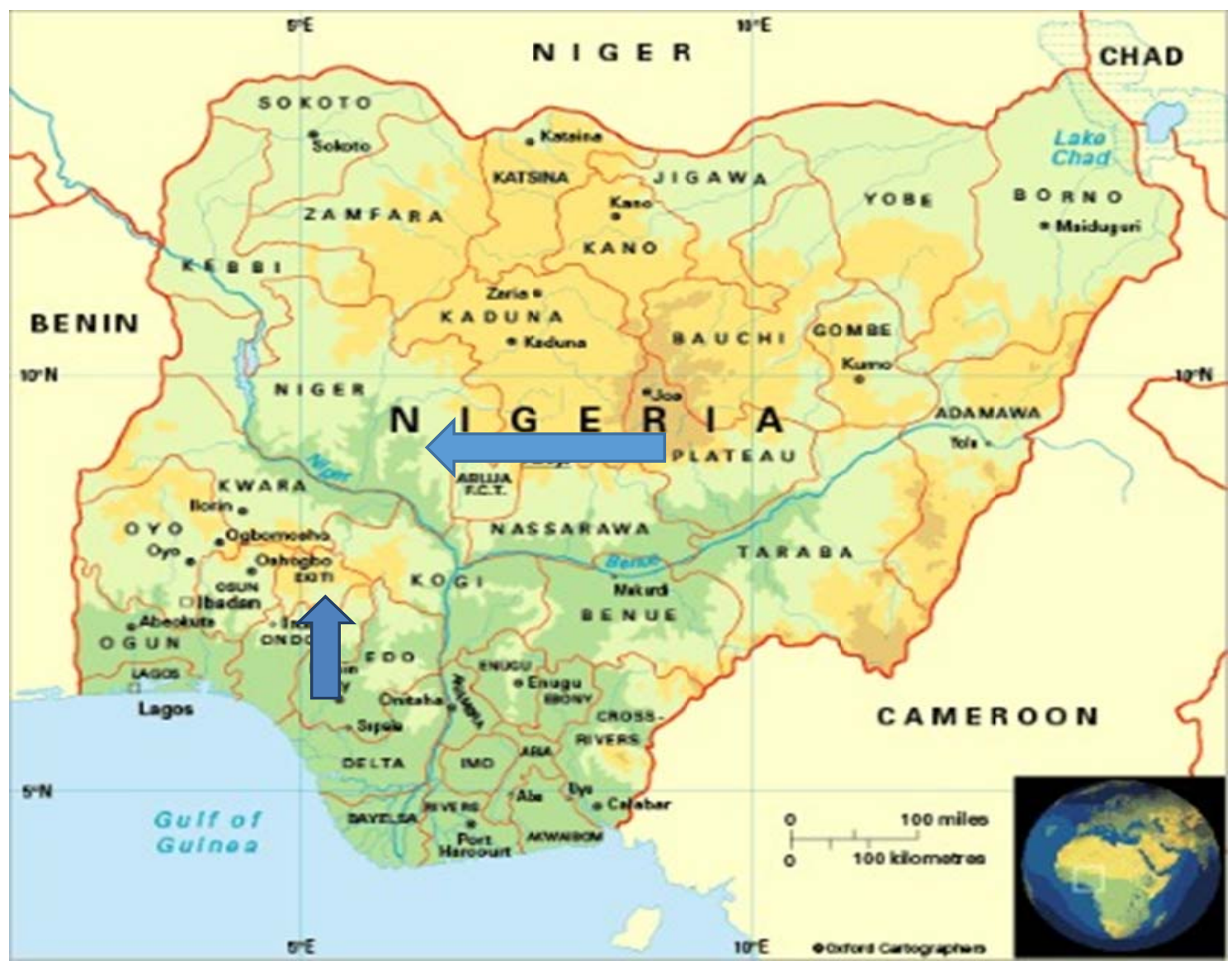

Figure 1. Twin Nigerian study sites.

\section{Field Data Representation and Analysis}

In this section we shall represent and analyze data from the different instruments applied in the research. In following this process two things were borne in mind: first, not all data gathering techniques allow scaling; second, there was need to represent study findings this way so as to create the ground for pulling together results from both sites in order, ultimately, to make for better understanding of how each variable affects farmers.

\section{Results From Marriage-Education Surveys}

In representing responses based on survey questions the results of which are displayed in Table 1, we placed the age for early marriage between 14 and 17 for females and between 17 and 20 for males.

Data in the Table 1 show that 91 out of 100 farmers from these two locations indicated they married early while 51/100 stated they did not acquire any formal education before entering marriage. Whereas a number as low as 17 people out of the 41 who claimed having some level of formal education indicated interest in going back to school to improve themselves, 98/100 stated being aware that having no (good) education is linked to poverty just the same way 95/100 admitted that their socioeconomics would have been different if they had good education. All 100 respondents stated that having no good education negatively affects their children in the present and would also affect them badly in the long run. It is not surprising that 83 out of the 100 farmers said they know having some good education helps farmers to acquire (new) knowledge for better farm 
management of other aspects of life. In like manner 97/100 declared their preparedness to discourage their children from marrying within the indicated age brackets. As it were 97/100 admitted there is a link between early marriage and poverty.

Table 1

The Impact of Early Marriage and Level of Education on Agriculture in SSA

\begin{tabular}{lllll}
\hline \multicolumn{2}{l}{ Questions } & Yes & No & Declined \\
\hline A & Did you marry early in your life? & 91 & 9 & 0 \\
B & Did you attend school at all before you got married? & 46 & 51 & 3 \\
C & Do you plan to go back to school for higher education? & 17 & 83 & 0 \\
D & Do you think that not having good education makes people poor & 98 & 0 & 2 \\
E & Do you think your life would have been different if you had had good education? & 95 & 4 & 1 \\
F & Does the fact of not having good education affect your children now? & 100 & 0 & 0 \\
G & Do you think that not having good education will affect your children in future? & 100 & 0 & 0 \\
H & Do you think having good education would help a farmer have better knowledge? & 83 & 11 & 6 \\
I & Would you encourage your children, male and female, to marry early? & 3 & 97 & 0 \\
J & Do you think that early marriage stands in the way of people's progress in life? & 83 & 9 & 8 \\
K & Do you see how early marriage is connected with poverty in gereral? & 97 & 3 & 0 \\
\hline
\end{tabular}

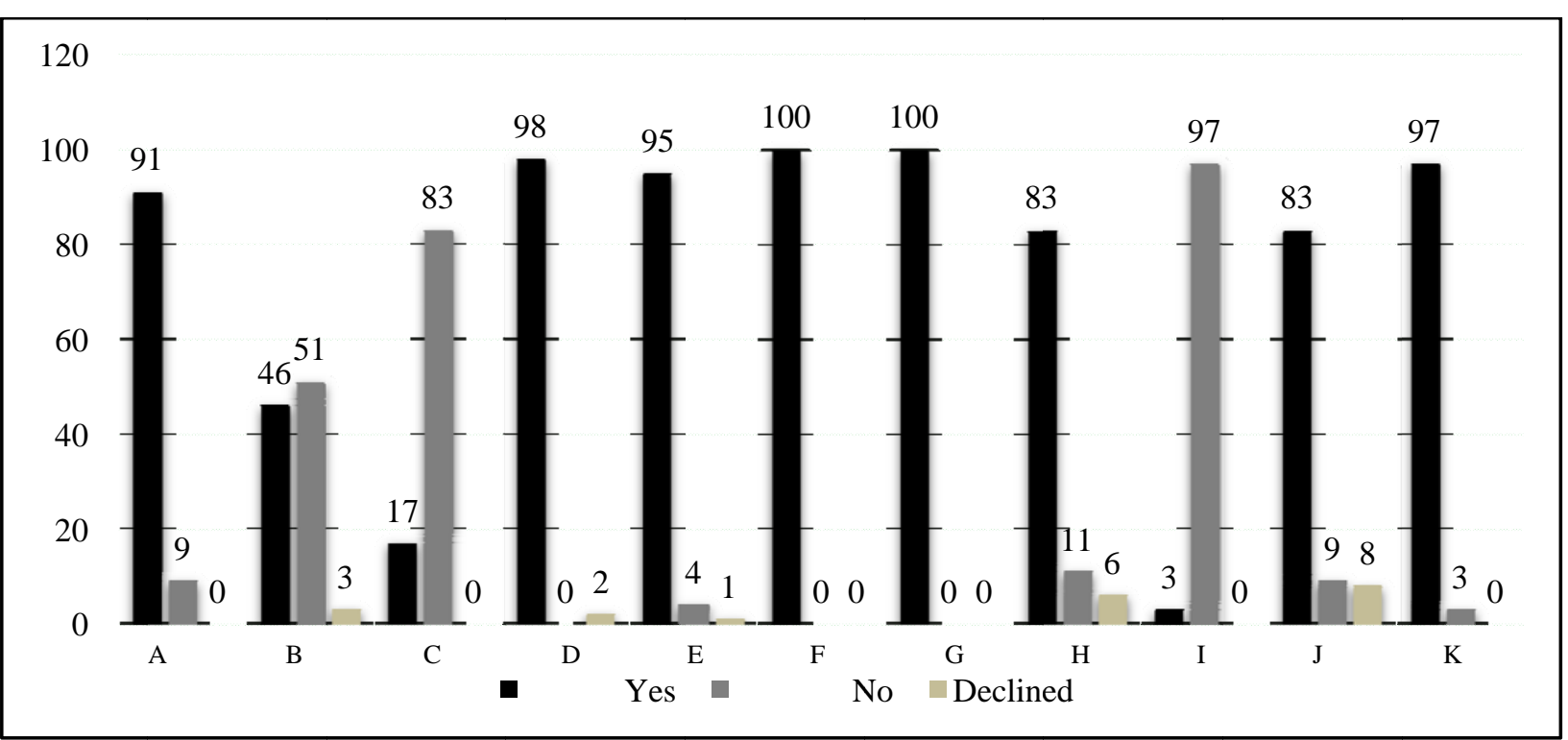

\section{Results from One-on-One Interviews}

When study participants were engaged in in-depth interviews, many reported they married early due to social institutional influence and pressure from parents and peers. Many others said they did so for lack of any inspiration to do any other thing to the contrary. These two feedbacks strongly suggest how early marriage itself becomes a snag in the way to pursuing other life ambitions and aspirations especially education. Looked at from the other side of the equation, it is easy to decipher how early marriage inhibits both male and female farmers from formal education and also prevents them from acquiring self-improving skills. Those who married early with little or no education tend to have larger families. Farmers who fall within this group also experience higher incidence of poverty; the same group of farmers are low in motivation to improve. Though such farmers work very hard, they find it difficult to afford the basics of life. 
This is not surprising with only 43 out of the 100 participants, interviews revealed, passed through primary education, while only 26 of them managed to step up to secondary education though not all of them finished up. Environment made a lot of difference as over half of those who passed through and finished secondary education are from the second study site (Abia State). However, regardless of the location, these are able to combine farming with other economically beneficial activities like teaching, trading and weaving.

With large families and many children to care for farming households in the other group experience high level of poverty which translates into low socioeconomics. Children born into such households experience higher degree of poverty, a cycle they find difficult to break. Similarly, many such children take after their parents in marrying early and forfeiting education and all its attendant benefits; this is notwithstanding that all the study participants who themselves married early vowed to dissuade their children from doing the same.

On the other hand, it was found that those who did not marry early fared better economically than their counterparts; this is more so for those with meaningful education. Famers who fall into this group also tend to have smaller family sizes; exhibit higher level of motivation to push themselves higher up the radar of social mobility just as they also strive to push their children for higher and better education. Finally, those in this group tend to diversify their means of livelihood through teaching, trading, horticulture, mini agro processing, and membership in social clubs among others.

Further interviews revealed that farmers who waited till they reached between 22 and 30 years of age do far better than those who married before that age range. This almost always offered them time go to school for formal education with additional advantages including but not limited to the practice of bricolage. Appendix Figure A1, A2, and A3 tell the story of a woman who, in addition to engaging in extensive farming is also a primary school teacher and runs her own mini agro processing mill. She buys large quantities of pealed, dry cassava flakes from Ukum-Benue farmers, which she processes into flour the end product which she sells to large-scale buyers mostly from Southwestern parts of Nigeria for conversion into food.

At the center of Zaki-Biam market space in Ukumland of Benue State, Nigeria, is a skills acquisition center as is displayed in Appendix Figure B2 owned by a farmer. The owner of the Atakpa College, as it is called, blames his fellow indigenous farmers for not diversifying. "Farmers from our land are poor because they do not go to school and do only farming; but I am educated, traveled out and came back to build my school and still do a lot of farming” (Fieldnotes: Zaki-Biam-August 12, 2014).

There are few other examples to illustrate the impact of education on farming in Nigeria and SSA; however, they are infinitesimally insignificant to make any big difference in the background of a mass of other farmers whose personal and social capital are low.

\section{Evidence From Direct Observation}

Close, direct observation revealed that this epidemic of poverty ravaging farming households where the heads married early is worse when they did not push themselves into any kind of education, formal or informal. Conversations with them and their children everyday brought to brighter light the fact that they do not have much to show for the extensive labor and time they invest in farm work. Their nutritional intake is too poor to support good health making them more vulnerable and susceptible to diseases. Just like their parents, talks with children from these households failed to indicate any drive for things relating to self-enhancement through formal and informal education. The short metanarratives reduced in the following tables (Tables 2 and 3) are factored in here to illustrate how the suffrage family heads who married early and did not acquire any good 
education trickles over and reflects in their children in many sticky ways. These are experiences from direct encounters with children from families where the heads typify the two variables this study tracks.

Table 2

Farming Stops School/Education

One fateful day we ran into two young girls who walked pass behind where we were stationed for this study; it was 8:30 am. They were armed with weeding hoes. We intercepted them with questions on where they were going; as was suspected, they were going to weed some part of a farm their mother had contracted for money. This was to raise money for school-related issues, they claimed. Every effort to persuade them to go back home and join others at a school opposite our residence failed. Instead the two young sisters-15 and 12 years old — still went to the farm through another pathway. At our request they brought their mother who explained she had no money to provide them with school uniform and books; completing the work was imperative for the money. Meanwhile, the school term had already rolled into the fourth week. Our promise to provide the said money was not welcome. We walked over and met the school Headmaster who explained the two girls had never enrolled in school before; their parents prefer sending them to the farm. "There are many children like them in our community", the Headmaster quickly added. In the end, the two sisters went back and spent the whole day at the farm. As a daily routine we observed children like the two sisters frequent the pathways to farms and markets with their parents. May be these parents were handing over to them a "tradition" their own parents bequeathed them (Fieldnotes: 8:30 am, April 21, 2014).

\section{Table 3}

\section{How Market Inhibits Schooling}

On a certain Kaydo market day (Wednesday) when schools were in session, we stood at the intersection of three villages. Feigning to be interested in buying some goods some children and their mothers were carrying — yams, tomatoes and peppers among others-we stopped and talked with as many as we could. Our findings include:1) the children were all between 8 and 12 years old; 2) at least 1 out of every 5 of them had not started schooling; 3 ) each of them covered two to three miles onfoot from home to the market; 4) they do this many times every week; 5) communicating with them in simple English was impossible- our research guide helped out in each case; 6) most shockingly, at least 3 out of every 6 of the mothers to these children never entered school for one day before they got married and never did after they married (Fieldnotes: 8:00-10:00 am, July 18, 2013).

\section{Evidence From Social Organization}

With responses from questionnaires and interviews and data from direct observation, the need arose to seek for more answers to our study questions. This was done through digging beyond the immediate study participants by applying a kind of archaeological probing into the content of the people's social organization. In the social organizational setting of Ukum-Benue, for example, it is the norm that a young man is given portions of land for his own farming and for setting up his own hut ("ate”) only when he takes a wife (Bohannan, 1953). Forde (1964) confirm this to be the case among the Tiv of Central Nigeria and the Yako of Southeast Nigeria: "A man first takes up farmland when he marries: that is, when he first brings a wife to live with him in an independent household" (Forde, 1964, p. 19). By observing this rite of passage among the Tiv, the "or $u$ 
$y a$ "- the compound head who is also the oldest man therein-exercises his customary obligation of giving the newly married man portions of land to help him start his own family. "It is considered the duty of the compound head to see that the men of his compound have sufficient land” (Bohannan, 1953, p. 50)—-the birth right of every male in by being born into this agnatic group.

The Tiv compound $(y a)$ is usually a cluster of many families bound together by close links of agglutination and complex genealogies traceable to a common father. The politics of "compounding" serves the purpose of social belonging, ownership and inheritance regulations within a social space—-the "tar" as "[...] a place, but primarily a peopled place [...], the area inhabited by a lineage” (Rubingh, 1969, p. 65; Bohannan, 1989, p. 1). Uchendu (1965) also documents that among the Igbo of Southeast Nigeria (the second study site) it is within the compound and kindred into which a male is born that he has entitlement to land and social belonging in general so much that outside this agnatic group a man has no existence and so no right even to association: "An Igbo without umunna — a patrilineage - [a close equivalent of the Tiv sense of kindred] is an Igbo without citizenship both in the world of man and in the world of the ancestors” (Uchendu, 1965, p. 12).

The essence of this inclusion of data from the social organization of our study sites is to point out that this conferment of entitlement over portions of land on a young man when he marries significantly helps in stampeding young men into taking wives early since, without doing so they would continue to farm for their fathers (Bohannan, 1953) and so still not counted as men in the traditional sense of the term. This customary norm works hand-in-glove with the other cultural norm of placing an unequaled value on begetting children to help him in work especially males who will succeed him.

The other side to the story is that, in this stampede into marriage, many young men in these environments forfeit schooling with a few of them managing to enter into but often never finish primary education. This is shown in the interview responses from a greater majority of the young married men who participated in this study: they either did not finish primary or secondary education before they married. They were also among those with large families of sometimes more than one wife and many children.

On the other hand, this male-centered customary norm extends its rippling effects to young girls as well. If young men must marry early, they must marry equally young girls who, by virtue of that are eluded by opportunities for schooling. This explains why over 85 percent of females who participated in this study indicated they married early and already had as many as three to five children; they either never schooled or dropped out of it.

\section{Synthesis of Study Findings}

Following the results from all data collection instruments applied in this study, some number of points stand out, which go a long way to inform us on how the two variables of early marriage and lack of good education affect farmers in SSA. It is arguably the case that when people among farming households marry early within the age ranges selected for males and females in this study they experience hardships in the remaining part of their lives. The poverty incidence they grapple with comes with a chain of other related implications of that singular action. These include blocking the chances for formal and even informal education. With the establishment of large families, they restrict themselves to only farming for food production and trading off of their produce; ironically, after these efforts they are unable to provide good nutrition, shelter, medication and other basic necessities of life.

A significant part of the poverty such farming families suffer comes from the fact that they depend 
exclusively on food they produce and from the meager proceeds they realize from sales of some of their produce. With little or no education, hardly any practice of bricolage, and inability to diversify into other economic activities for better and guaranteed means of livelihood, their chances at some progress beyond food production for consumption remain highly improbable.

\section{Discussion: Education for Development}

The results from the different instruments with which we collected data for this study on the two variables overwhelmingly point to one thing that operates in a twist of consequences: early marriage inhibits many young people from schooling or formal education; lack of good education in turn enhances early marriage and the establishment of large families; the two play off on each other to foster a cycle of sticky poverty; overall, these problems shed light, at least partly, on why productivity in agriculture in SSA is still far from performing at full potential.

These findings also provide the ground for our argument the core of which is that, for this twin-problem to be appropriately and sustainably addressed, education, in its formal and informal forms must be put in focus. It is our evidence-based stance that without education, poverty especially in SSA where the populations are predominantly rural and depend mainly on agriculture will loom even larger. Education is a major player and key instrument in the whole fight to reduce poverty and put the economy of SSA on a faster, sustainable pace. It puts the power of self-transformation in people's hands so that they in turn contribute meaningfully to the GDP of their nations. It is in this light that we totally agree with the FAO and UNESCO-IIEP (2006) ${ }^{3}$ joint manual in making the case that, "Education for rural people is crucial for achieving both the Education for All (EFA) goals, and the Millennium Development Goals (MDGs) of eradicating extreme poverty and hunger [....]” (p. 7). It is also on account of the role of education as a key tool in achieving poverty eradication, food security, durable peace and sustainable development that the World Food Summit of the United Nations (1996) stressed the need for increased access to education for the poor and disadvantaged populations including rural people. For the same reason, the Johannesburg World Summit on Sustainable Development (UN, 2002) also emphasized the role of education to the same effect.

The call for aggressively investing in the education of farmers in SSA is predicated not only on the findings of this study but also on similar findings chronicled in the analysis of FAO and UNESCO-IIEP (2006) summed up in the following points: The vast majority of the world's 852 million chronically undernourished people live in rural areas in the developing world; there are 860 million illiterate adults around such niches a majority of whom are women; there are 130 million children in such areas who do not go to school with the greater majority of that wooping number being girls; in SSA in particular, the vast majority of the population is rural. As such, the seminar concludes that, "[...] in order to achieve the MDGs, a special effort must be made towards promoting rural development and fostering better living conditions for the rural poor” (p. 12).

We make the case here by stressing that these efforts to uplift rural people from poverty and food insecurity will bear no fruits without factoring education programs that speak to the need of farmers of SSA. For, based on our study findings, it is mainly due to lack of (good) education that young men and girls rush into marriage and invariably into poverty further pushed by the various family and social institutional reasons already identified. Hunger, undernourishment, poor living conditions, poverty cycle, lack of motivation to

\footnotetext{
${ }^{3}$ FAO and UNESCO-IIEP. 2006, Education for Rural People in Africa. Food and Agriculture Organization of the United Nations, Rome, Italy.
} 
climb out of the condition among others are some of the ways lack of education impacts affected farmers. The overall reason for this situation lies in the fact that, by not having education and marrying early, these farmers remain at very low levels of both personal and social capital and so low in agricultural productivity. With the human development index (HDI) of SSA communities still low as have been noted by UNDP (2008-2009) ${ }^{4}$ and African Development Report (2002), we argue that education is key to helping rural farmers of SSA to improve themselves and their families. As the Forum for Agricultural Reseacrh in Africa (FARA, 2006) documents, "Limited human capital in Africa's agricultural sector is a significant constraint to enhancing the performance of local agricultural institutions for sustainable growth and poverty reduction in the continent” (p. 1).

The whole point of this discussion is summed up in the point that, human beings as the agents of agricultural and general social and economic development must themselves be developed in order to develop their environment. It is because this power lacks in the majority of those who took part in this study that they are poor and the agriculture sector in SSA suffers major setbacks. We round off this section by stressing that, "The improvement of a country's human resource capacity for productivity is a prerequisite for social and economic development” (Lindley et al., 1996, p. 1). As Pudasaini (1983), Welch (1970), Nelson and Phelps (1966) and Shultz (1975) have demonstrated in Nepal, "Education contributes to agricultural production and productivity through the worker and allocative effects”. This is a model for SSA.

\section{Conclusion: Policy Recommendations}

The position of this study is that, if the problems associated with early marriage and lack of (good) education in relation to agricultural productivity in SSA are to be overcome, Governments of SSA should strive to realize the MDG of universal education for all; this, if well implemented, will help reduce this dual problem.

Agricultural education should be taken more seriously at all levels of education to reflect the needs of SSA.

In addition to formal education, non-formal education, often provided on a private-public scale, “[...] is needed for training farmers, farm families and workers for capicity-building in a wide range of rural organizations and groups” even as Lindley et al. (1996, p. 1) has documented.

For farmers who do not have formal education to benefit from capacity-building agriculture-related programs, there is the corresponding need for governments of SSA to foster and fund competency development in agricultural education and extension. Ghadei et al. (2005) study confirms this.

Entrepreneurship education leading to the acquisition of skills for small businesses should be established for farmers without formal education as the studies of Garba (2010), Awogbenle and Iwuamadi (2010), Oghojafor et al (2009), Akpomi (2009) recommend.

Similarly, funding for on-going research on the best techniques to provide need-based non-formal education programs for SSA farmers should be a policy priority.

To make these policy visions operable and effective, it is further strongly recommended that farmers and their community leaders-as major stakeholders and players—should be fully involved in the whole process. This will help to see that the make-up components of non-formal education programs intended for them are not imposed from outside but should reflect their needs and incorporate their indigenous technical knowledge (ITK) when and where possible.

${ }^{4}$ UNDP, 2008-2009, Human Development Report: Achieving Growth with Equity. United Nations Development Programme (UNDP), Nigeria. 
These policy recommendations are based on the fact that agrarian change does not happen by accident but by the continually growing productive power of farmers themselves. It is on account of this that we have followed the trail of data from our field research to make the case that education is the key to addressing the problems arising from early marriage and lack of (good) education especially as they very significantly negatively impact farming households in SSA. It is the conclusion of the present contributor to this on-going dialogue, that education — especially in relation to the two variables tracked in this study—is a must-tool for improving agricultural productivity in SSA.

\section{References}

Achodo, C. C. (2000). Conflict and post conflict patterns, issues, impact on economic development and poverty cycle in countries in Africa. African Forum on Poverty Reduction. Public Forum Paper, 1-12.

ADR. (2002). Africa in the World economy: Rural development for poverty reduction in Africa. The African Development Bank.

AfDB. (2012). Africa food security: Highlights of the food security situation in Africa. Quarterly Bulletin (p. 3).

Ake, C. (1996). Democracy and development in Africa. Washington, DC: The Brookings Institution.

Akpomi, M. E. (2009). Achieving Millennium Development Goals (MDGs) through teaching entrepreneurship education in Nigerian Higher Education Institutions (HEIs). European Journal of Social Sciences, 8(1), 152-158.

Annor-Frempong, I. (2012). Prospects of agricultural development in Africa: Implications for agricultural education and training. Third Ruforum Biennial Meeting 24-28, 1019-1036.

Arias, M. A., \& Ibanez, A. M. (2013). Agricultural production amidst conflict: The effects of shocks, uncertainty and governance of Non-State Armed actors. Retrieved from https://www.aeaweb.org/aea/2014conference/program/retrieve.php?pdfid=60

Awogbenle, A. C., \& Iwuamadi, K. C. (2010). Youth unemployment: Entrepreneurship development programme as an intervention mechanism. African Journal of Buniess Management, 4(6), 831-835.

Bohannan, P. L. (1953). The Tiv of Central Nigeria. London: International African Institute.

Bohannan, P. L. (1968). Tiv Economy. Evanston: Northwestern University Press.

CICRED. (2007). Rural populations and Agrarian transformation in the global south. A CICRED Policy Paper, number five.

European Commission. (2016). Sahel: Food and nutrition crisis. Retrieved from http://ec.europa.eu/echo

FAO. (2002). The State of Food Insecurity in the World (4th ed.). Food and Agriculture Organization, FAO.

Forde, D. (1964). Yako studies. London: Oxford University Press.

Forde, D., \& Scott, R. (1946). The native economies of Nigeria. London: Faber and Faber Limited.

Garba, A. S. (2010). Refocusing education system towards entrepreneurship development in Nigeria: A tool for poverty eradication. European Journal of Social Sciences, 15(1), 140-150.

Ghadei, K., Sujan, D. K., \& Nayak, R. (2005). Copentency development in gricultural education and extension: Analysis and advocacy. A Working Paper.

Jouanjean, M. A. (2013). Targeting infrastructure development to foster agricultural trade and market integration in developing countries: An analytical review. Retrieved from https://www.odi.org.uk/sites/odi.../8557

Kimenyi, M., Adibe, J., Djire, M., Jirgi, A. J., Kerga, A., Deressa, T. T., Pugliese, J. E., \& Westbury, A. (2014). The impact of conflict and political instability on agricultural investments in Mali and Nigeria. Africa Growth Initiative Working Paper (17).

Krishna, A., \& Zackman, R. (2008). Technology-Mediated Open and Distance Education (Tech-MODE) for agricultural education and improved livelihoods: Country Case Studies. A Commonwealth Working Paper.

Lindley, W. I. et al. (1996). Education in agriculture: Links with development in Africa. FAO Researh, Extension and Training Division.

Mcdonald, S. (2000). Drought in Southern Africa: A study for Botswana. Proceedings from XIII International Conference on Input-Output Techniques.

Morgan, W. B., \& Solarz, J. A. (1994). Agricultural crisis in Sub-Saharan Africa: Development constraints and policy problems. The Geographical Journal, 160(1), 57-73.

Nelson, R. R., \& Phelps, E. S. (1966). Investment in humans, technical diffusion and economic growth. American Economic Review, 56, 69-75. 
Oghojafor, B. E. A., Kuye, O. L., Sulaimon, A. A., \& Koji, P. S. (2009). Empowering Nigerian youths for national economic development: The role of entrepreneurship education. Journal of Research in National Development, 7(2), 1-8.

Omorogiuwa, O., Zivkovic, J., \& Ademoh, F. (2014). The role of agriculture in the economic development of Nigeria. European Scientific Journal, 10(4), 133-145.

Oyeshile, O. A. (2015). Ethnic conflict resolution and development in Africa: The ontological, ethical and political imperatives. University of Ibadan, Nigeria.

Pudasaini, S. M. (1983). The effects of education in agriulture: Evidence from Nepal. American Journal of Agricultural Economics, 65(3), 509-515.

Rubingh, E. (1969). Sons of Tiv: A study of the church among the Tiv of Central Nigeria. Michigan: Baker Book House.

Shultz, T. W. (1975). The vlue of ability to deal with disequilibrium. Journal of Economic Literature, 13, 827-46.

Uchendu, V. C. (1965). The Igbo of Southeast Nigeria. New York: Northwestern University.

Welch, F. (1970). Education in production. Journal of Political Economy, 78, 35-59.

Zachmann, R. (2014). Synthesis of Eight Country Case Studies. In J. Alluri, \& R. Zachmann (Eds.), Technology-Mediated Open and Distance Education for Agricultural Education and Improved Livelihood in Sub-Saharan Africa: Country Case Studies,. Commonwealth of Learning, Vancouver, Canada. 


\section{Appendix A}

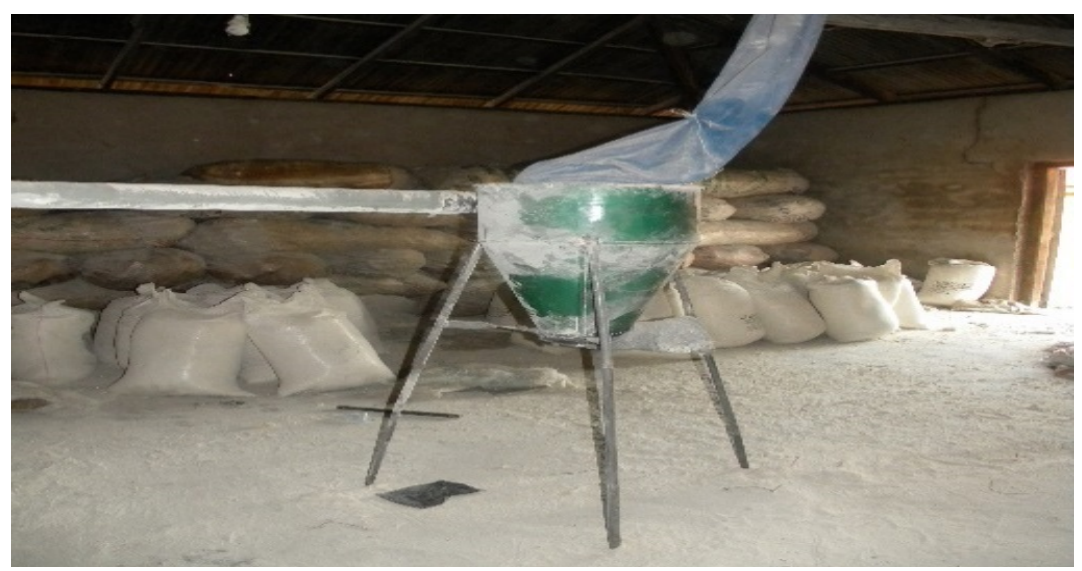

Figure A1. Dry Cassava Flakes Mill.

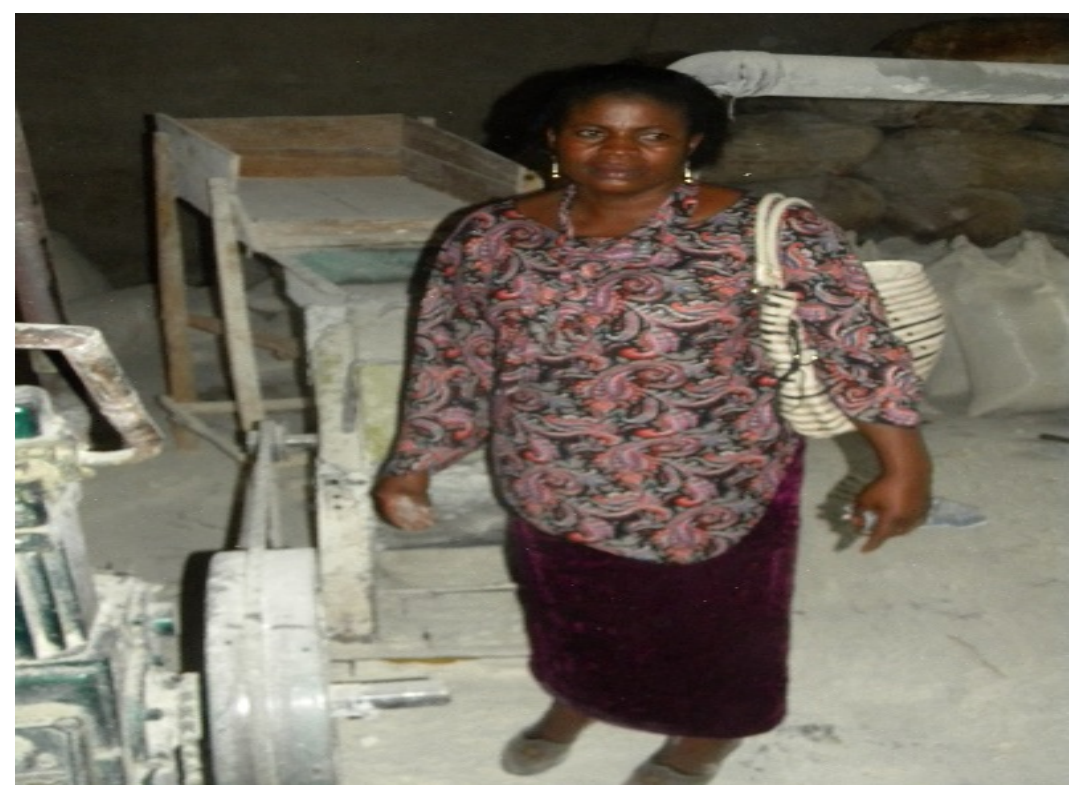

Figure A2. Farmer-Teacher-Miller (A case of Bricolage).

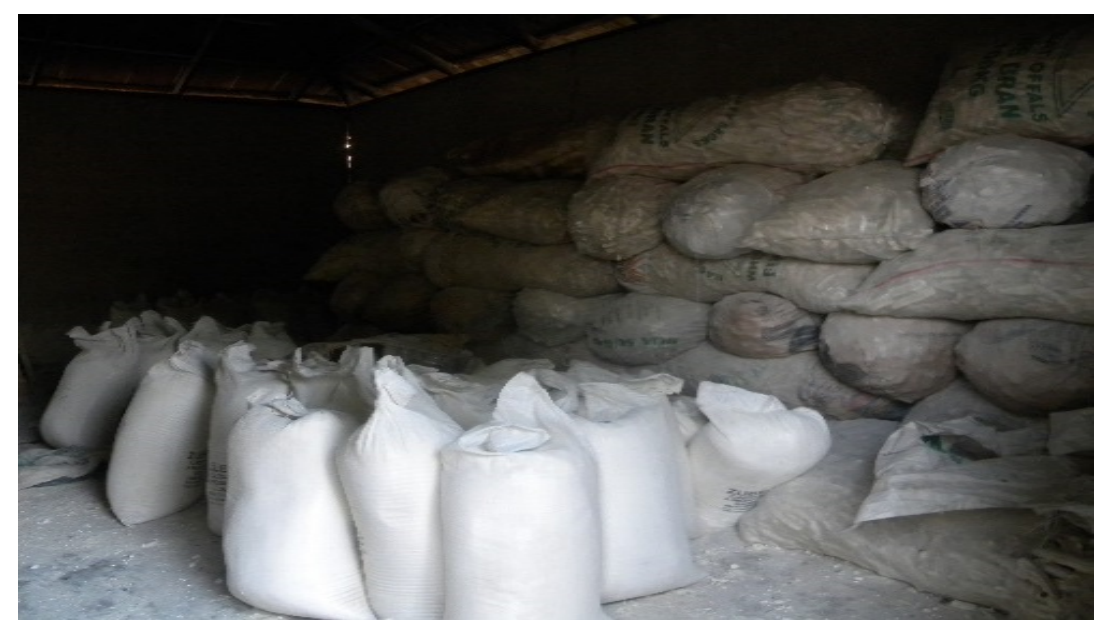

Figure A3. Bags of Cassava Flour. 


\section{Appendix B}

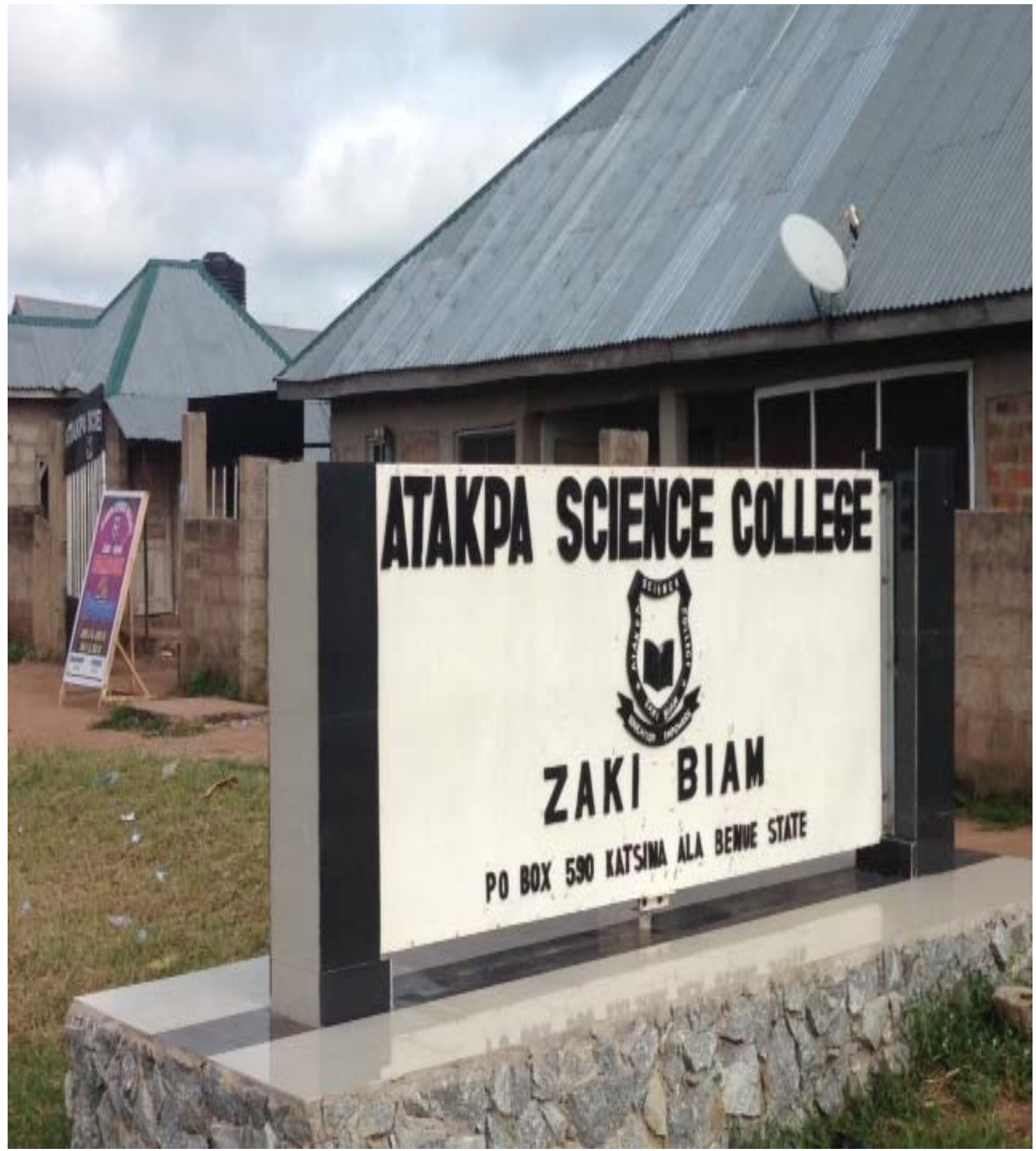

Figure B1. A Farmer’s Skills Acquisition Center at Zaki-Biam in Benue State. 